\title{
KECEMASAN MAHASISWA PERAWAT SEBELUM MENGIKUTI UJIAN KETRAMPILAN DI LABORATORIUM
}

\author{
Suyanto, Retno Isrovianingrum \\ Fakultas Ilmu Keperawatan Universitas Islam Sultan Agung Semarang, \\ suyanto@unissula.ac.id
}

\begin{abstract}
Introduction: Implementation of skills evaluation in the laboratory is necessary to see how far the ability has been achieved. Objective structured clinical examination (OSCE) becomes one of the evaluation techniques used. the purpose of this study is to know prevalence of the anxiety and the factors that cause anxiety before following the OSCE in first-degree nursing students. Methodology: This research is a descriptive research, as many as 89 respondents selected by using simple random sampling. The questionnaire used was Nursing Skills Anxiety Scale Test (NSTAS). Results: 65 respondents (73\%) experienced anxiety with most of the sexes were women $(89,9 \%)$, and 56 respondents $(62.9 \%)$ were 18 years old. Factor's related to anxiety included environment $(50,5 \%)$, exam it self $(44,9 \%)$ and observer (44,9\%). Discussion: there is a need for further research on the impact of anxiety before taking the OSCE examination with graduation rates on each skill performed.
\end{abstract}

Keywords: Anxiety, Objective structured clinical examination (OSCE)

Abstrak : Pendahuluan: Pelaksanaan evaluasi ketrampilan di laboratorium sangat diperlukan untuk melihat sejauh mana kemampuan yang telah dicapai mahasaiswa. Objective structured clinical examination (OSCE) menjadi salah satu tehnik evaluasi yang digunakan. tujuan dari penelitian ini adalah diketahuinya kejadian kecemasan dan faktor-faktor yang menyebabkan kecemasan sebelum mengikuti OSCE pada mahasiswa keperawatan tingkat pertama. Metodologi : penelitian ini merupakan penelitian deskriptif, sebanyak 89 responden dipilih dengan menggunakan simple random sampling. Kuesioner yang digunakan adalah Nursing Skills Test Anxiety Scale (NSTAS). Hasil : 65 responden (73\%) mengalami kecemasan dengan sebagian besar jenis kelamin adalah perempuan $(89,9 \%)$, dan 56 responden $(62,9 \%)$ berusia 18 tahun. Faktor-faktor yang memiliki nilai tinggi antaralain faktor situasi lingkungan (50,5\%), ujian (44,9\%) dan sikap observer (44,9\%). Diskusi : perlu adanya penelitian lanjut mengenai dampak dari kecemasan sebelum mengikuti ujian OSCE dengan tingkat kelulusan pada setiap ketrampilan yang dilakukan oleh mahasiswa.

Kata kunci : Kecemasan, Objective structured clinical examination (OSCE)

\section{PENDAHULUAN}

Ketrampilan merupakan kompetensi dasar yang harus dimiliki oleh seorang calon perawat. Kompetensi dapat diartikan sebagai suatu kemampuan yang dimiliki oleh seseorang dan 
dapat diobservasi dalam menyelesaikan suatu pekerjaan atau tugas dengan standart kinerja performance yang ditetapkan. Adapun kompetensi mencakup tiga aspek yaitu pengetahuan (kognitif), sikap (afektif) dan ketrampilan (skill) (DIKTI. 2016). Teori terkait menyatakan bahwa standart minimal kompetensi ketrampilan dapat diketahui dengan dilakukannya uji kompetensi melalui ujian ketrampilan di laboratorium dengan metode OSCE/OSCA. Metode OSCE dapat diartikan sebagai suatu metode penilaian mahasiswa atau lulusan pendidikan kesehatan yang lebih kompleks (Turner \& Dankoski, 2008).

Bentuk evaluasi dari ketrampilan mahasiswa keperawatan adalah dengan dilakuknnya ujian ketrampilan di laboratorium dengan menggunakan model OSCE. OSCE dianggap sebagai format uji kedua yang paling bagus oleh $53(35,1 \%)$ responden, dan 56 $(37,1 \%)$ juga menyarankan agar OSCE perlu digunakan lebih banyak daripada format penilaian lainnya (Nasir et al, 2014).

Ujian merupakan salah satu cara mengevaluasi mahasiswa terhadap suatu materi belajar dan juga menjadi sumber kecemasan bagi mahasiswa (Basuki,Ismet 2015). Ujian ketrampilan di laboratorium harus dapat dilaksanakan secara cepat dan tepat serta harus dilakukan secara lengkap tanpa terlewati satu unsur pun dalam waktu uji yang singkat $( \pm 10$ menit tiap satu keterampilan), untuk mendapatkan nilai yang bagus (Arief, Suwadi, \& Sumarni, 2003). Hal tersebut memungkinkan timbulnya kecemasan pada mahasiswa keperawatan sebelum melaksanakan ujian lab klinik keperawatan. Alasan lainnya bahwa ujian OSCE dilaksanakan pada setiap akhir semester baik pada mahasiswa di tingkat awal sampai mahasiswa tingkat akhir program akademik. Mahasiswa tingkat awal yang belum terpapar dengan OSCE memungkinkan terjadinya kecemasan (Mavis, 2010).

Penelitian yang terkait menyatakan bahwa ada beberapa faktor yang dapat mempengaruhi terjadinya kecemasan pada mahasiswa saat menghadapi ujian ketrampilan. Faktor-faktor tersebut antaralain adalah sikap pengawas ujian (observer), suasana lingkungan ujian, ketrampilan mahasiswa, ujian, dan perasaan internal yang dirasakan oleh mahasiswa yang bersangkutan seperti perasaan khawatir selama proses ujian atau perasaan tidak yakin kalau akan lulus ujian ketrampilan (Yang et al ,2014). Tujuan penelitian ini adalah diketahuinya kejadian kecemasan pada mahasiswa keperawatan tingkat pertama yang akan melakukana ujian ketrampilan di laboratorium serta faktor-faktor yang mendukung kecemasan mahasiswa tersebut.

\section{METODE}

Desain penelitian yang digunakan dalam penelitian ini adalah deskriptif design. 89 responden dilibatkan dalam penelitian ini, adapun tekning pengambilan sample yang dipakai adalah simple random sampling. Kriteria inklusi penelitian ini adalah seluruh mahasiswa tingkat pertama yang baru pertama kali melakukan ujian ketrampilan di laboratorium dengan model evaluasi berupa OSCE. Sedangkan kriteria eksklusi pada penelitian ini adalah mahasiwa yang saat pengambilan data tidak hadir. Data diambil pada bulan januari 2018. Instrumen yang digunakan adalah kuesioner berupa NTSAS. 
Pengambilan data dilakukan saat berada di ruang isolasi sebelum mahasiswa melakukan ujian ketrampilan. Uji analisis data yang digunakan adalah uji distribusi frekuensi dengan melihat jumlah dan persentase masing-masing variabel yang ingin dilihat.

\section{HASIL DAN PEMBAHASAN \\ Hasil}

Tabel 1. Karakteristik Responden berdasarkan jenis kelamin dan umur $(\mathbf{n}=\mathbf{8 9})$

\begin{tabular}{lcc}
\hline Variabel & Frekuensi & Prosentase \\
\hline Jenis Kelamin & & \\
Laki-laki & 6 & 10,1 \\
Perempuan & 80 & 89,9 \\
Jumlah & 89 & 100 \\
Umur & & \\
$\mathbf{1 7}$ & 8 & 10 \\
$\mathbf{1 8}$ & 56 & 62,9 \\
$\mathbf{1 9}$ & 21 & 23,6 \\
$\mathbf{2 0}$ & 4 & 4,5 \\
Jumlah & 89 & \multicolumn{2}{c}{100} \\
\hline
\end{tabular}

Tabel.1 didapatkan data bahwa jenis kelamin perempuan mendominasi sampel dengan jumlah 80 responden $(89,9 \%)$. Sedangkan untuk umur yang paling banyak adalah umur 18 tahun sebesar 56 respondn $(62,9 \%)$.

TABEL.2 Kejadian kecemasan pada responden $(n=89)$

\begin{tabular}{lcc}
\hline \multicolumn{1}{c}{ Variabel } & Frekuensi & Prosentase \\
\hline Cemas & 65 & 73 \\
Tidak cemas & 24 & 27 \\
Jumlah & 89 & 100 \\
\hline
\end{tabular}

Tabel.2 menunjukkan bahwa angka kejadian mahasiswa yang mengalami kecemasan saat akan melakukan ujian ketrampilan adalah sebanyak 65 responden $(73 \%)$.

Tabel.3 Gambaran faktor-faktor kecemasan pada responden $(\mathrm{n}=\mathbf{8 9})$

\begin{tabular}{cccccc}
\hline variabel & $\begin{array}{c}\text { Sangat tidak } \\
\text { setuju (\%) }\end{array}$ & $\begin{array}{c}\text { Tidak } \\
\text { setuju (\%) }\end{array}$ & $\begin{array}{c}\text { Netral } \\
(\%)\end{array}$ & $\begin{array}{c}\text { Setuju } \\
(\%)\end{array}$ & $\begin{array}{c}\text { Sangat setuju } \\
(\%)\end{array}$ \\
\hline $\begin{array}{c}\text { Perasaan intern } \\
\text { mahasiswa }\end{array}$ & $36(40,4 \%)$ & $\begin{array}{c}26 \\
(26,6 \%)\end{array}$ & $\begin{array}{c}20 \\
(22,5 \%)\end{array}$ & $\begin{array}{c}7 \\
(7,9 \%)\end{array}$ & - \\
\hline Integritas fisik & $11(12,4 \%)$ & $\begin{array}{c}28 \\
(31,5 \%)\end{array}$ & $\begin{array}{c}28 \\
(31,5 \%)\end{array}$ & $\begin{array}{c}20 \\
(22,5 \%)\end{array}$ & $2(2,2 \%)$ \\
\hline $\begin{array}{c}\text { Ketrampilan } \\
\text { mahasiswa }\end{array}$ & $9(10,1 \%)$ & $\begin{array}{c}11 \\
(12,4 \%)\end{array}$ & $\begin{array}{c}48 \\
(53,9)\end{array}$ & $\begin{array}{c}19 \\
(21,3 \%)\end{array}$ & $2(2,2 \%)$ \\
\hline $\begin{array}{c}\text { Sikap pengawas } \\
\text { ujian }\end{array}$ & $1(1,1 \%)$ & $\begin{array}{c}13 \\
(14,6 \%)\end{array}$ & $\begin{array}{c}35 \\
(39,3 \%)\end{array}$ & $\begin{array}{c}27 \\
(30,3 \%)\end{array}$ & $13(14,6 \%)$ \\
\hline $\begin{array}{c}\text { Situasional } \\
\text { (lingkungan) }\end{array}$ & $4(4,5 \%)$ & $\begin{array}{c}11 \\
(12,4 \%)\end{array}$ & $\begin{array}{c}29 \\
(32,6 \%)\end{array}$ & $\begin{array}{c}35 \\
(39,3 \%)\end{array}$ & $10(11,2 \%)$ \\
\hline Ujian & $4(4,5 \%)$ & 10 & 35 & 30 & $10(11,2 \%)$ \\
& $(11,2 \%)$ & $(39,3 \%)$ & $(33,7 \%)$ \\
\hline
\end{tabular}

Tabel.3 didapatkan hasil bahwa faktor situasional (lingkungan) yang paling tinggi dengan $35(39,3 \%)$ responden mengatakan setuju, faktor yang kedua adalah faktor ujian ketrampilan sebanyak $30 \quad(33,7 \%)$ mengatakan setuju. Faktor yang terakhir adalah faktor sikap pengawas ujian dirasakan sebagai faktor yang membuat cemas dengan $27 \quad(30,3 \%)$ responden mengatakan setuju. 
Hasil analisis data didapatkan bahwa mahasiswa dominan mengalami kecemasan sebelum melakukan ujian ketrampilan di laboratorium degan metode OSCE. Hasil penelitian ini sesuai dengan penelitian terdahulu yang menyatakan bahwa OSCE adalah metode penilaian yang paling menimbulkan kecemasan dan siswa mempersiapkan lebih banyak untuk OSCE daripada ujian lainnya (Brands \& Scoonheim-Klein, 2009). Hasil penelitian terkait lainnya menyatakan bahwa 53\% responden merasa gugup saat akan melakukan ujian OSCE (Nasir et al, 2014). Hasil penelitian relevan lainnya menunjukkan bahwa OSCE menyebabkan lebih banyak kecemasan daripada format penilain lainnya (Mahsa et al, 2017).

Kecemasan merupakan suatu kondisi emosi dan pengalaman subjektif individu terhadap objek yang tidak jelas dan spesifik akibat antisipasi bahaya yang memungkinkan individu melakukan tindakan untuk menghadapi ancaman. Situasi ini menimbulkan perasaan yang tidak menyenangkan dalam bentuk perasaan gelisah, takut atau bersalah (Supriyantini, 2010). Teori lainnya menyatakan bahwa kecemasan dapat diartikan sebagai sebuah reaksi emosional yang berlebihan, sensitif, dan depresi yang tumpul (TaylorClift,Morris, Kovacs, \& Rottenberg, 2011). Pendapat lainnya menyatakan bahwa kecemasan merupakan bentuk penolakan dari seorang individu yang memunculkan perasaan takut (Stuart \& Sundeen, 2013). Dalam konteks kecemasan menghadapi ujian ketrampilan merupakan sebuah respon emosi yang dialami oleh individu sebagai suatu reaksi dalam menghadapi ujian yang bisa memberikan dampak psikis dan fisik.
Kecemasan dalam mengahadapi ujian ketrampilan dapat dipengaruhi banyak faktor, antara lain observer, situasi lingkungan, ujian itu sendiri, jenis kelamin dan sebagainya.

Jenis kelamin pada penelitian ini dominannya adalah perempuan. Hal ini juga dapat mempengaruhi tingkat kecemasan yang dialami. Hal ini sesuai dengan pendapat yang menyatakan bahwa wanita atau perempuan lebih peka terhadap emosinya, sehingga hal tersebut yang akan mempengaruhi perasaan cemasnya (Kaplan,Saddock,\& Grabb, 2010). Hasil penelitian ini berbeda dengan penelitian lainnya yang menyatakan bahwa jenis kelamin tidak berpengaruh banyak terhadap kecemasan siswa sebelum melakukan ujian. Jenis kelamin wanita memiliki skor akhir yang relatif tinggi pada nilai OSCE yang didapat (Brands \& Scoonheim-Klein, 2009). Penelitian lain menunjukkan bahwa jenis kelamin perempuan tidak menunjukkan skor kecemasan yang tinggi saat mengikuti OSCE (Hadi et al, 2017). Hal ini menunjukkan bahwa jenis kelamin bukan merupakan faktor yang menentukan kecemasan dalam menghadapi ujian OSCE tetapi dapat menjadi faktor pendorong terjadinya kecemasan pada siswa.

Umur responden paling banyak berumur 18 tahun. Umur juga bisa mempengaruhi kecemasan. Pendapat yang relevan menyatakan bahwa kriteria diagnostik seseorang mengalami gangguan kecemasan pada umumnya adalah berusia 18 tahun atau lebih (Ramaiah, 2007). Pendapat lain menyatakan bahwa umur berkaitan erat dengan tingkat maturasi (kematangan) individu. Tingkat maturasi inividu akan mempengaruhi 
tingkat kecemasan (Potter \& Perry, 2005).

Hasil analisis data menunjukkan bahwa ada 3 faktor yang memiliki nilai yang cukup tinggi pada mahasiswa yang mengalami kecemasan. Tiga (3) faktor tersebut adalah situasi saat ujian berlangsung, ujain itu sendiri dan yang terakhir adalah sikap pengawas ujian (observer). Ketiga faktor tersebut memiliki nilai yang cukup besar, meskipun dalam penelitian ini tidak menganalisis faktor mana yang paling besar pengaruhnya terhadap kecemasan yang dialami mahasiswa.

Situasi lingkungan saat ujian merupakan faktor yang paling tinggi nilainya. Hal ini sejalan dengan hasil penelitian lainnya yang menyatakan bahwa adanya perasaan khawatir dari mahasiswa mengenai suasana lingkungan selama dilakukan ujian ketrampilan keperawatan (Yang et al, 2014). Penelitian terkait lainnya menyatakan bahwa Lingkungan pembelajaran dan situasi lingkungan merupakan faktor penting dalam proses pembelajaran (Papastavrou, et al. 2010). Mahasiswa keperawatan tingkat pertama yang baru pertama kali melakukan ujian ketrampilan sangat memungkin memunculkan kecemasan khususnya karena mereka berada pada lingkungan atau situsai yang baru.Pendapat relevan lainnya menyatakan bahwa seseorang yang berada pada lingkungan baru atau asing, lebih mudah mengalami kecemasan dibandingkan dengan seorang individu yang berada pada lingkungan yang sudah biasa ditempati (Stuart\& Sundeen, 2013).

Faktor kedua yang memiliki nilai cukup tinggi adalah faktor ujian itu sendiri. Ujian ketrampilan merupakan stimulus Makin besar stressor, makin besar respon stress yang ditimbulkan. Pengkondisina stressor masing-masing orang sangat berbeda-beda. Beberapa mahasiswa yang akan mengikuti ujian OSCE ada yang menganggap bahwa OSCE adalah stressor yang kecil atau ringan, tetapi ada sebagian besar lainnya yang menganggap bahwa OSCE adalah stressor yang berat sehingga menyebabkan kecemasan (Potter\& Perry, 2005).Hasil penelitian terkait menunjukkan bahwa meskipun siswa sudah menyiapkan dengan sebaik mungkin dalam menghadapi ujian metode OSCE tetapi kecemasan yang diraskan oleh siswa juga tetap meningkat (Mahsa et al, 2017).

Faktor ketiga yang memiliki nilai cukup tinggi sebagai faktor yang dapat mempengaruhi kecemasan adalah sikap pengawas ujian (observer). Hasil penelitian kualitatif yang dilakukan oleh Budi, wardhaningsih, dan afandi (2017) menyatakan bahwa sikap penguji yang kurang siap seperti memberikan komentar saat ujian membuat mahasiswa menjadi gerogi. Hasil penelitian lainnya menyatakan bahwa saat pengawas mengamati mahasiswa melakukan ujian ketrampilan, mahasiswa menjadi terancam dan hal tersebut menimbulkan kecemasan (Marwaha, 2011).

Keterbatasan dalam penelitian ini adalah penelitian ini adalah penelitian awal pada satu institusi dengan satu variabel, belum membandingkan antara tingkat kecemasan dengan nilai akhir OSCE mahasiswa, belum membandingkan tingkat kecemasan antara tingkat pertama dengan tingkat kedua, ketiga dan keempat. 


\section{SIMPULAN}

Kecemasan dialami oleh mahasiswa keperawatan tingkat satu yang akan mengikuti ujian ketrampilan di laboratorium. Hal ini dapat mempengaruhi performance saat melakukan tindakan selama pelaksanaan ujian.

Perlu kiranya dilakukan tindakantindakan tertentu untuk mengurangi kecemasan sebelum dilakukannya ujian ketrampilan. Untuk penelitian selanjutnya perlu dilihat sejauh mana pengaruh kecemasan tersebut dapat mempengaruhi kelulusan ketrampilan yang diujikan.

\section{DAFTAR PUSTAKA}

Arief, Suwadi, Sumarni. (2013). Hubungan kecemasan menghadapi ujian skills lab modul shock dengan prestasi yang dicapai pada mahasiswa FK Universitas Gajah Mada angkatan 2000. http://www.ebookspdf.org/downl $\mathrm{oad} / \mathrm{kecemasan} \cdot \mathrm{html}$

Basuki, Ismet dkk. (2015). Asesmen Pembelajaran. Remaja. Bandung; Rosdakarya Offset..

Brand, H,S., \& Schoonheim-Klein, M. (2009). Is the OSCE more stressful? Examination anxiety and its consequences in different assessment methods in dental education. Europe Journal Dentis Education. ;13(3):147-53. doi: $10.1111 / \mathrm{j} .1600-$ 0579.2008.00554.x.

Budi, Y,S., Wardhani,S.,\& Afandi,M. (2017). Faktor-Faktor yang Mempengaruhi Kecemasan Mahasiswa Program Studi D III
Keperawatan Dalam Menghadapi Ujian Skill Laboratorium: Studi Mixed Methods di STIKES Banyuwangi. Thesis,UMY

DIKTI. (2016). Uji Kompetensi Nasional Progam Pendidikan D3 Keperawatan untuk Profesionalitas Tenaga Perawat. http://belmawa.ristekdikti.go.id Hadi et al.(2017). Impact of test anxiety on pharmacy students' performance in Objective Structured Clinical Examination: a cross-sectional surve. Journal of IJPP;DOI: 10.1111/ijpp.12389

Kaplan, HI, Saddock, BJ \& Grabb, JA. (2010). Kaplan-Sadock Sinopsis Psikiatri Ilmu Pengetahuan Prilaku Psikiatri Klinis. Tangerang; Bina Rupa Aksara.

Mahsa et al. (2017). Measurement of the levels anxiety, self-perception of preparation and expectations for success using an objective structured clinical examination, a written examination, and a preclinical preparation test in Kerman dental students. Journal of Education Health Promotion, 6: $28 . \quad$ doi: 10.4103/jehp.jehp_97_15

Mavis B. (2010). Assessing student performance. In: Jeffries WB, Huggett KN,

Marwaha S. Objective Structured Clinical Examinations (OSCEs), psychiatry and clinical assessment of skills and competencies (CASC) same evidence, Different Judgment. Medical School of Warwick Coventry UK. BMC Psychiatry. 2011: 1-6 
Nasir et al. (2014). Medical students' perception of objective structured clinical examination: a feedback for process improvement. Journal Surgical Education. ;71(5):701-6. doi: 10.1016/j.jsurg

Papastavrou, E., Lambrinou, E., Tsangari, H., Saarikoski, M. \& Leino-Kilpi, H. (2010). Student nurses experience of learning in the clinical environment. Nurse Education in Practice, vol. 10, no. 3, pp. 176-82 editors. An introduction to medical teaching. New York: Springer

Potter, P.A \& Perry, A.G. (2005).Buku Ajar Fundamental Keperawatan : Konsep, Proses, Dan Praktik.Edisi 4.Volume 1.Alih Bahasa : Yasmin Asih, dkk. Jakarta, EGC

Ramaiah. (2007). Kecemasan: Bagaimana Mengatasi Penyebabnya. Jakarta; Pustaka Obor.

Stuart, G.W., dan Sundden, S.J. (2013). Buku Saku Keperawatan Jiwa, Edisi 3. Jakarta; EGC.
Supriyantini. (2010). Perbedaan Kecemasan Dalam Menghadapi Ujian Antara Siswa Program Reguler dengan Program Akselerasi. Tesis. Universitas Sumatra Utara. Sumatra Utara

Taylor-Clift, A., Morris, B., Kovacs, M., \& Rottenberg, J. (2011). Emotion modulated startle in anxiety disorders is blunted as a function of comorbid depressive episodes. Psychological Medicine, 41, 129139.

Turner, J., Dankoski, E. (2008). Objective Structured Clinical Exams: A Critical. Review. https://www.stfm.org/f

Yang, R., Lu, Y., Chung, M. \& Chang, S. (2014). Developing a short version of the test anxiety scale for baccalaureate nursing skills test - A preliminary study. Nurse Education in Practice, vol. 14 , no. 6 , pp. 586590. 